\title{
RESEARCH PAPER \\ Applying a bioeconomic optimal control model to charcoal production: the case of slash-and-burn agriculture in Mexico
}

\author{
Fernando Arrocha ${ }^{1}$, and Mauricio G. Villena ${ }^{2}$ \\ ${ }^{1}$ Facultad de Ciencias Económicas y Administrativas, Universidad de Concepción. Casilla (Box) 1987, \\ Concepción, Chile. \\ ${ }^{2}$ Escuela de Negocios, Universidad Adolfo Ibáñez. Avenida Diagonal las Torres 2640, Peñalolén. Santiago, Chile.
}

\begin{abstract}
F. Arrocha, and M.G. Villena. 2012. Applying a bioeconomic optimal control model to charcoal production: the case of slash-and-burn agriculture in Mexico. Cien. Inv. Agr. 39(3): 489-504. This paper analyzes the relationship between rural poverty and forest land management for the case of charcoal production under slash-and-burn agriculture. An optimal control model is used to determine how a representative household makes decisions about the allocation of labor and about the forest areas to exploit. In turn, these decisions affect the renewable resource base available to the community. The proposed optimal control model for charcoal production is based on the Pascual and Barbier (2007) model of slash-and-burn agriculture. This theoretical model is calibrated with data from the community of Chunkanán, Campeche, Mexico. The simulation and comparison of the traditional slash-and-burn approach to forest management with the Forest Management Program for the Exploitation of Timber Resources (FMPETR), developed by the regulatory authority as a policy for the use and conservation of forest resources, showed that the traditional approach, but not the FMPETR, is sustainable from an ecological point of view and efficient from an economic point of view, implying that households allocate an optimal amount of labor and forest biomass. This result suggests that the FMPETR is a suboptimal policy and shows that there is room for improvement in terms of the design and implementation of policies aimed at providing economic and social incentives leading to the sustainable management of natural resources.
\end{abstract}

Key words: Charcoal production, forest management, rural poverty, rural households.

\section{Introduction}

Natural resource conservation policies have focused on the elaboration and application of management and conservation plans for forests harboring plentiful flora and fauna. These for-

Received May 12, 2011. Accepted February 2, 2012. Corresponding author: mauricio.villena@uai.cl ests contribute key environmental services to maintain a local, regional and global ecological balance.

In this context, the elaboration of management and conservation plans for forest resources requires methods of analysis that allow a better understanding of the economic and social incentives leading to the promotion of the optimal management, use and conservation of the natural resource. 
Subsistence in certain indigenous communities depends primarily on the use of forest resources, particularly in Latin America. These communities typically conduct forest management based on the collective ownership of land, using factors such as work, land and forest resources as productive inputs to ensure economic, social and environmental stability. In the specific case analyzed in this study, the local economies are diversified to include agricultural production, livestock and forest activities, backyard activities, handicrafts and wage labor within and outside localities close to the Natural Protected Biosphere Reserve of Los Petenes, Mexico (Arrocha, 2007). The forest resource is particularly important to maintain the income and welfare levels for local households.

Therefore, decision makers and makers of public policies whose work involves the management and conservation of natural resources have focused their efforts on the creation of programs for community forest management to improve the management, use and conservation of forest resources, as well as increasing the production and monetary incomes of agricultural-forest households. Currently, charcoal is produced under a slash-and-burn system in small patches that are subsequently used for agricultural production. The felling strategy involves a selective cutting of forest species found in the region. These species include Ja'abin (Piscidia piscicula), Chukum (Pithecellobium albicans), Ts'its'ilche' (Gymnopodium floribundum), Tsalam (Lysiloma latisiliquum) and Katsin (Acasia gaumeri). The felling process leaves trunks $30 \mathrm{~cm}$ in height to allow subsequent regeneration. Charcoal is produced in artisanal furnaces that are built from cut firewood, arranged in pyramids, and sealed with earth and grass.

The forest policy of the State of Campeche, Mexico, involves a type of management based on polygons within which forest exploitation is conducted. The purpose of this policy is to improve the use and conservation of forest surfaces and to increase the productivity of agricultural-forest households. The elaboration of plans for community forest management has received substantial financial support during the past decade. These plans are characterized by forest plantations managed under a system of exploitation polygons.

The proposal suggested by the Forest Management Program for the Exploitation of Timber Resources (FMPETR) includes important changes in the approach to managing community forests. Specifically, the FMPETR suggests the following: (i) determine only one polygon for community forest exploitation, (ii) cut the forest species of the region to clear productive surfaces, (iii) reforest with the same species, (iv) define a production zone for charcoal within the polygon, and (v) suggest a 15- to 20-year rotation for the productive lots. Table 1 compares the traditional slash-and-burn approach to forest management with the FMPETR.

The main objective of this study is to evaluate the effects of the application of the FMPETR relative to the use of biomass and the amount of forest

Table 1. Characteristics of the traditional forestry slash-and-burn management approach and of the Forest Management Program for the Exploitation of Timber Resources (FMPETR).

\begin{tabular}{ll}
\hline Traditional Forest Management & FMPETR \\
\hline Slash-and-burn & $\begin{array}{l}\text { Slash-and-burn } \\
\text { Rotating polygon, batch management for production } \\
\text { delimited }\end{array}$ \\
Small areas (patches) for production & $\begin{array}{l}\text { Semi-thinning of the productive area (cut all trees) } \\
\text { Limited access to a single polygonal area for community } \\
\text { felective logging and low impact (retaining trunks } 30 \mathrm{~cm} \text { in height }\end{array}$ \\
Free access to the total resource of the community forest area & Production of charcoal in the area within the polygon \\
Charcoal production site a handcrafted oven & Land rotation period of 15 to 20 years \\
\hline
\end{tabular}


work through the use of an optimal bioeconomic model for the production of charcoal. Specifically, the results of the analysis of a bioeconomic model based on optimal control are used to compare the FMPETR exploitation strategy with the current traditional strategy of forest management. This comparison allowed us to evaluate the working hypothesis that the traditional forest management approach based on slash-and-burn management is efficient in the long term, unlike the application of FMPETR, in terms of the amount of forest work assigned and the levels of use of forest biomass by charcoal-producing households.

\section{Materials and methods}

The dynamic optimal control model. Pascual and Barbier (2007) have formulated a theoretical model to analyze the use of forest lands typically used for agriculture by rural communities of Mexico. They have also proposed a methodology for applying the model to real data (Pascual and Martínez-Espiñeira, 2006). Based on the theoretical conceptualization of Pascual and Barbier (2007), the present study proposes a theoretical model of charcoal production. This model furnishes the basis for the empirical analysis presented in this paper.

The specific modifications to the original model by Pascual and Barbier (2007) are the following: a) the conceptual adaptation of the forest biomass parameter, represented by $Q(t)$, defined as the amount of firewood extracted from a specific surface, in terms of the density of valuable forest species; b) the utility function, defined as an aggregated expenditure function in consumer goods satisfying primary needs from the total monetary income of the household; c) budget constraints depending on the monetary income derived from the production of charcoal plus the income from other productive activities and from transfers of funds (families and government); and d) the production function, based on the extent of forest surface cut, the amount of work used to produce charcoal and the amount of biomass used.
These changes allow the bioeconomic evaluation of the traditional forest management approach and the application of the FMPETR. This evaluation is formalized through a dynamic and autonomous model. The model uses a long-term scenario and positive discount rates that maximize the utility function of the households subject to restrictions on the production, the budget and the amount of biomass used by charcoal-producing households.

Dynamic optimal control model for production of charcoal under a slash-and-burn system. The utility function for a representative producing household is assumed to be an aggregate function of expenditures on consumable goods satisfying primary needs. These expenditures are obtained from the total monetary income of the household $(m)$. The direct utility function $U=U(m)$ assumes a continuous $U^{\prime}(m)>0$. The utility function is also assumed to be twice differentiable, nondecreasing and concave, with $U^{\prime \prime}(m)<0$. Leisure time is not included in the utility function of the households because it is considered to be predetermined in each productive cycle at a positive discount rate of $r$.

The annual production of charcoal, $\mathrm{CH}_{i}(t)$, is determined by the slash-and-burn system and the technology used for artisanal production. The production of the $\mathrm{i}$-th producing household in a period $(t)$ is conditioned by the amount of forest surface used in production, $g \mathrm{Li} / \mathrm{bi}$; the amount of work used in charcoal production exclusive of biomass cutting, $(1-g) \operatorname{Li}(t)$, i.e., the amount of work required for the construction and demolition of the traditional charcoal furnace, as well as for the packing of the charcoal; and by the amount of biomass available for exploitation by a forest user, $Q_{i}(t)$. Formally:

$$
C H_{i}(t)=f_{i}[g L i / b i,(1-g) L i(t), Q i(t)] .
$$

Specifically, the production is a function of the surface used to produce charcoal, $g \mathrm{Li} / \mathrm{bi}$.

It consists of the total work assigned to the production of charcoal, $L i$; the proportion of work assigned to the cutting or clearing of forest land, $g$; and the 
measure of intensity of the clearing or land cutting, $b i$ (for example: the number of hours required to cut a hectare of surface for the production of charcoal). The second argument of the equation, (1-g) $L i(t)$, represents the amount of work needed for charcoal production, depending on the productive work in other areas different from the clearing or cutting of secondary vegetation. Finally, the third term of the production function is conditioned by the total amount of biomass used in annual production, $Q_{i}(t)$. The amount of biomass can be modeled as a renewable resource because the traditional forest management approach used by the producers allows recovery over time intervals of 8 to 12 years through land rotation. The recovery of the forest resources depends primarily on the timber species composition on the fallow land.

The budget restriction available for charcoalproducing households is defined by the amount produced, the income from activities other than the production of charcoal and the transfers of money that occur:

$$
m_{i}=C H_{i}(t)+c\left[T_{i}-L_{i}(t)\right]+E_{i}
$$

The budget function indicates that the annual income of a producing household is conditioned by the amount $\mathrm{CH}_{i}(t)$ produced plus the earned income obtained within and external to the community, $c\left[T_{i}-L_{i}(t)\right]$, where $\mathrm{c}$ is the rate that defines the real salary $(w / p)$, $\mathrm{T}$ is the discretionary work diversified within and external to the productive sector, and $\mathrm{Li}(\mathrm{t})$ is the total work used in the production system plus the real exogenous income including the transfers of funds among households, government or other incomes, $E(t)$. Additionally, it is assumed that the partial derivatives of the production function satisfy $f_{j} \geq 0, f_{j j} \leq 0$ and $f_{j k}=f_{k j} \geq 0$ for $k \neq j$, where $i$ identifies the households and $j$ identifies the arguments of the charcoal production function.

Dynamics of forest biomass. The dynamics of forest biomass is fundamental to the analysis, as charcoal-producing households require the use of forest lands to obtain this basic input for production. These surfaces are maintained in fallow land as a fundamental part of the system of traditional forest management used in slashand-burn agriculture.

The accumulation of biomass results from the intrinsic growth of forest ecosystems, the recovery of affected surfaces (burned) and agricultural surfaces (recovered through a forest process) in a rotation used for production (Lucio, 2006), where $\mathrm{Q}(t)$ is the amount of biomass of plant species suitable for this productive activity.

Specifically, the amount of annual average biomass is conditioned by the index of forest biomass, which considers the relative weight $\rho$ of the tree species used to produce charcoal and the average forest biomass within the surface used, $\mathrm{X}(t)$, as shown in the following equation:

$Q(t)=\rho X(t)$

where the amount of forest biomass in the field results from

$X(t)=\frac{(V g(t)-\underline{V g})}{(\overline{V g}-\underline{V g})}$,

where $\underline{V g}$ and $\overline{V g}$ are the minimum and maximum weights of the tree species, respectively, and $V g(t)$ is the total weight of the biomass stock within a specific surface.

If the surface selected by the producer does not include particular tree species used in the production of charcoal, we have $\underline{V g}=0$ and $0 \leq X(t)=\frac{V g(t)}{\overline{V g}} \leq 1$. Additionally, $\rho$, the relative weight attached to the index of forest biomass, would have the value 1 because it is related to the forest biomass.

The stock function for forest biomass, $\operatorname{Vg}(t)$, is determined by the parameter $\lambda$, which does not vary over time, and the variable Wo, which represents the average existing biomass in the productive surface used: 
$\operatorname{Vg}(\mathrm{t})=\lambda \ln [\mathrm{Wo}]$

The total amount of biomass used by the community is conditioned by the parameter $\lambda=\rho \overline{V g(t)}$, the maximum percentage of biomass used in the production of charcoal, multiplied by the natural logarithm (ln) of the average forest biomass present in the surface, Wo.

Therefore, the forest biomass existing in the fallow lands, which changes from one period to the next, is represented by $Q(t)=\frac{\dot{\mathrm{W}}}{\mathrm{Wo}}$, where $\dot{\mathrm{W}}_{\mathrm{o}}$ is the amount of biomass used from one period or productive cycle to another (considering a productive cycle equal to one chronological year) and Wo is the amount of biomass present on the fallow surfaces.

The equation shows that if the producing households allow the land to remain fallow for a longer period of time, the biomass on the surface will increase. It is assumed that under the traditional system of community management, the forest biomass depends on the remaining total fallow land available in the community as a whole (López, 1997).

$$
\dot{W} O=\gamma-\frac{k \sum_{i=1}^{n} \frac{L i}{a i}}{A} W O
$$

Thus, the amount of fallow land exploited for the production of charcoal will only be conditioned by the total number of producing households, $n$. The community brings the fallow land under the charcoal production system with biomass use Wo. This rate of forest exploitation is determined by the parameters $a_{i}=b_{i} / g_{i}$. These parameters represent the intensity of charcoal production per unit area (hectare) by a household practicing traditional forest management. The intensity of the work required to cut the biomass (the average number of hours required to cut one hectare) is denoted by $b_{i}$, and the percentage of work devoted to biomass cutting that contributes to production is $g_{i}$. In equation (5) below, the term $L_{i}$ in the numerator represents the total hours of work dedicated to firewood cutting, and parameter $A$ represents the total area of fallow land and productive land under the control of the community. Parameter $k$ measures the increase or decrease in land use according to the type of forest management ( $k=1$ for the traditional approach, $k \neq 1$ for the FMPETR) relative to the balance in the management of forest biomass.

Equation 5 shows that the growth rate of forest biomass on the land surface is determined by the intrinsic growth rate of the secondary vegetation, $\gamma$ (Ibíd.), minus the decrease of forest biomass resulting from exploitation by the producing households under the type of forest management in effect on the land surface.

Assuming that all charcoal-producing households are identical, the forest biomass present in the community and available under communal access changes from one period to another as follows:

$\dot{Q}=\lambda\left(\gamma e^{-q}-k \Theta \frac{L_{i}}{a_{i}}\right)$

Equation 6 shows that the amount of forest biomass changes according to the changes in the intrinsic natural growth rate, $\gamma e^{-q}$, of the secondary vegetation and forest species (including a depreciation of natural capital $e^{-q}$ ) minus $\Theta \equiv \frac{n}{A}$, which is the amount of households (n) using the surfaces (A) within the common land, multiplied by the intensity of work $\frac{L_{i}}{a_{i}}$ associated with production and by the type of forest management $k$ used for charcoal production.

Optimal assignment of amount of work and forest biomass made by charcoal-producing households. The optimization problem associated with charcoal-producing households is formally established as an autonomous dynamic model based on a long-term scenario and the assumption of a positive discount rate $r$.

Therefore, the choice of an amount of work by each household is a problem that involves the determination of the amount of work assigned to 
charcoal production. This choice is restricted by the production function, the productive income and the time that maximizes the welfare of the producing households based on a selected time horizon. If an infinite time horizon is selected, the problem is continuous in time and can be expressed as follows:

$$
V^{*}=\max _{L} \int_{t_{0}}^{t \rightarrow \infty} e^{-r t} U[m(t)] d t
$$

Assuming the restrictions on the equations of the production function, the budget restriction and the amount of biomass used by the representative household, i.e., equations (1), (2) and (6), the following Hamiltonian is obtained for the present value:

$$
\bar{H}[Q(t), L(t), \mu(t)]=U[m(t)]+\mu(t) \lambda\left[\gamma e^{-q}-\Theta k \frac{L}{a}\right]
$$

In this representation, the objective function is to maximize the utility function of the producing household subject to a budget restriction (m) that is primarily determined by the production function, with work as a control variable, the forest biomass as the state variable and the co-state variable $\mu(t)$ representing the shadow value of the amount of biomass used in a period $t$.

The Maximum Principle is applied to solve this optimization problem by approximation, using continuous time and assuming a previous solution, in addition to considering a stable state for the control, state and co-state variables: $\dot{L}=\dot{Q}=\dot{\mu}=0$.

The following equations are obtained under the assumption of first-order conditions for an optimal path with limit and cross-sectorial conditions:

$$
\begin{aligned}
& U^{\prime}(m)\left[\frac{f_{1}}{a}+(1+g) f_{2}-c\right]=\frac{\mu k \Theta \lambda}{a} \\
& \frac{\dot{\mu}}{\mu}+\frac{U^{\prime}(m) f_{3}}{\mu}=r+\gamma e^{-q}
\end{aligned}
$$

$$
\dot{Q}=\lambda\left[\gamma e^{(-q)}-\frac{k \Theta L}{a}\right]
$$

$$
\lim _{t \rightarrow \infty} \mu(t) Q(t)=0
$$

$$
Q(0)=Q_{0}
$$

The determining equation (9a) indicates that households use forest work until they obtain a profit from additional forest land, introducing their productive system, and that they use the remaining time for activities differing from charcoal production as the opportunity cost of work assignment. The other cost consists of the marginal value of the real salary plus the depreciation value of the forest biomass that the households incur. Moreover, a decreased value of the natural community capital is involved due to the surfaces introduced to production.

Equation (9b) is known as the optimal assignment rule for maintaining the amount of forest biomass. The unearned profit may be represented by the change in the amount of biomass when the present rate of marginal return is equal to the cost. This representation includes the rate of discount $r$ as the economic value of the biomass plus the additional cost associated with the expected growth of the forest biomass, $\gamma / W o$. The participation in the returns from the amount of forest biomass involves the present appreciation of this value, $\frac{\mu}{\mu}$, plus the increased additional profit from the amount of forest biomass due to the present charcoal production, $\frac{U^{\prime}(m) f_{3}}{\mu}$.

The equation of state (9c) describes the evolution of the forest biomass as influenced by parameter $k$. This dynamic behavior of the state variable involves an increase or decrease of the average amount of surface used by the community's households annually.

Finally, equation (9d) ensures that the households optimize the amount of biomass at the final time, where the returns from forest biomass tend to zero as the time horizon approaches infinity. 
The parameter of forest management $k$ clearly has a direct impact on the amount of forest biomass used by households but is limited by the cost of forest work and the returns from the existing forest resource (biomass).

The conditions cited above require that charcoalproducing households decide between two alternatives. The first option is the immediate use of the biomass as input for production. The alternative option is to leave these forest lands as unused fallow land to allow a greater amount of biomass to accumulate in the future.

This optimization problem is solved given the known values $\dot{L}=\dot{Q}=\dot{\mu}=0$. The long-term values corresponding to the stable state are obtained as follows:

$$
\begin{aligned}
& \dot{L}=0: \quad \lambda \Theta k f_{Q}=a(r+i)\left(f_{L}-c\right) \\
& \dot{Q}=0: \quad \gamma \exp (-q)=k \Theta \frac{L^{*}}{a} \\
& \dot{\mu}=0: \quad \mu^{*}=\frac{U^{\prime}(m) f_{3}}{r+i}
\end{aligned}
$$

where $f_{1} / a+(1-g) f_{2} \equiv f_{1} / a+(1-g) f_{2}$ represents the marginal product of the amount of biomass used and the amount of work applied to the production of charcoal. $f_{1}$ is the marginal product associated with the first argument of the production function, i.e., the forest-cutting activity, and $f_{2}$ is the marginal product associated with forest work other than cutting.

A system of two equations may be formulated based on these relations in $(Q, L)$. If we represent the values of the stable state by an asterisk, the shadow value of the long-term forest biomass is

$\mu^{*}=\frac{U^{\prime}(m) f_{3}}{r+i}$

A long-term balance for a representative household may be obtained by substituting (13) in (9a). If we substitute $Q=0$ and $\mu$, the equalities ( $9 \mathrm{a}$ ) and (9b) can be used to obtain the optimal path for forest work L, represented by

$\dot{L}=\frac{\lambda \Theta k f_{Q}-\left(r-e^{-q^{*}}\right) a f_{L}}{\theta a\left(f_{L}-c\right)^{2}-f_{L L}}$,

where $\theta$ is the marginal elasticity of the production of charcoal and a global concave measure of the utility function (Pascual and Barbier, 2007).

Comparative static analysis of the effect of forest management on work assignment and forest biomass in the proposed model. The amount of work and the optimal long-term forest biomass for the charcoal producers is sensitive to changes in the model parameters. The amount of biomass used for the production system is influenced by the forest management parameter $k$ representing the pressure on the resource. This relationship was considered in the analysis.

The FMPETR proposal suggests the adoption of a more intensive approach to forest management, aggregating a greater amount of work and biomass use to promote higher levels of production for producing households. Moreover, it seeks to regulate access to the zone of forest exploitation, as indicated by the polygon associated with community exploitation.

Following the logic of the model for charcoal production, it is considered that the amount of work and the balance of forest biomass are determined according to the number of households in the productive system, as well as by the marginal profit of work and the marginal cost associated with the unit of forest surface introduced to production.

From considerations of the balance equations of the model, we have the following:

$\dot{L}=0: \quad \lambda \Theta k f_{Q}=a(r+i)\left(f_{L}-c\right)$ 


$$
\begin{aligned}
& \dot{Q}=0: \quad \gamma \exp (-q)=k \Theta \frac{L^{*}}{a} \\
& \dot{\mu}=0: \quad \mu^{*}=\frac{U^{\prime}(m) f_{3}}{r+i}
\end{aligned}
$$

According to these specifications, the effects of the behavior of charcoal-producing households on the management of forest biomass can be described as follows. If households exploit low-stature deciduous and subdeciduous forests that offer high levels of biomass, $Q_{0}>\mathrm{Q}^{*}$, they can assign more time to forest activities. However, a larger amount of forest work dedicated to cutting would result in a decrease in biomass, $\dot{Q}<0$. Consistent with a stable path, we find that the amount of biomass and the work devoted to forest activities would achieve a dynamic balance during this period.

However, if households initially have access to forest lands with a low timber species biomass for charcoal production, i.e., $Q_{0}<\mathrm{Q}^{*}$, then the households must assign less time to forest activities. The households decrease their use of forest lands for production due to the marginal amounts of biomass resulting from the low density of the forest species used in charcoal production. This decrease in use would increase the level of forest cover for the community.

The process of productive forest management is determined by the average amount of work applied to production and by the social scale of the extraction of forest biomass. The degree of pressure on forest lands is described in this way and is represented by the rate of area-population $\Theta$. The process described above occurs endogenously in the community as a result of the internalization of the social costs resulting from the decrease of forest biomass and, therefore, from the decrease in the fallow land surface under community management.

The possible effects of the application of the FMPETR on the decisions by households are also analyzed with the model. In this model, forest management (the use of forest surface for production) is represented by parameter $k$, assumed equal to 1 for traditional slash-and-burn management. In contrast, the management of forest lands consistent with the FMPETR results in a value of parameter $k$ unequal to 1 . Parameter $k$ is unequal to 1 under the FMPETR because the productive use of forest lands reflects the average increase in cutting effort represented by $k \Theta \frac{L^{*}}{a}$. The increase in production proposed by the FMPETR assumes that the producing households will establish their production factors (the surface used, the forest work and the amount of biomass) without changing the technology used for artisanal production from charcoal furnaces or the slash-and-burn system.

The amount of forest work performed by the household and the amount of forest biomass allocated to households can be estimated if the internalization of social costs from the use of forest fallow lands is assumed. This problem was analyzed with an approximation to the increased long-term pressure of households on forest lands, using the parameter $k$ in the optimal level of $L^{*}$ and $\mathrm{Q}^{*}$.

Proposition 1. The condition necessary to obtain a unique balance in forest management, $k$, is provided by:

$a\left(f_{L L}-c\right) \geq F$, where $F=\left[\frac{(r+i) f_{Q}-\lambda \Theta / f_{\varrho Q}}{i}+\frac{f_{o}}{\mathrm{~L} /} / a\right]>0$

This condition states that the return rate from forest work is greater than or equal to the marginal cost of the current use of forest biomass but that this inequality does not hold for the following period.

Proof of Proposition 1. Taking the partial derivative of the forest work function with respect to the forest management parameter $k$, we obtain the following: $\frac{\delta \mathrm{L}^{*}}{\delta \mathrm{k}}=\mathrm{L}^{*} * \Theta$ where $\mathrm{L}^{*} * \Theta \geq 0$, subject to: $\frac{\delta \mathrm{L}^{*}}{\delta \mathrm{k}} \geq 0$. Then, $\mathrm{L}^{*} * \Theta \geq 0$ and $\Theta \geq 0$. Therefore, the inequality is satisfied: $a\left(f_{L L}-c\right) \geq F$, where

$F=\left[\frac{(r+i) f_{Q}-\lambda \Theta / f_{Q Q}}{i}+\frac{f_{Q}}{\mathrm{~L}^{*} / a}\right]>0$ Q.E.D. 
Equation 18 shows that in equilibrium, forest work by a representative producing household would increase under forest management until the return rate from forest work, $a\left(f_{L L}-c\right)$ , was greater than or equal to the exploitation cost of the amount of biomass introduced to the charcoal-production system.

The estimation of the marginal cost for households includes the reciprocal externalities on the rest of the community. These factors are completely internalized. Therefore, if the households are not subject to condition (9a), it is possible that the households will decide to perform less forest work given an increase in the producer density.

Proposition 2. Optimal forest management occurs when the total surface used by the producers is greater than or equal to the threshold for the social decrease of forest biomass, i.e., $\Theta \geq \Omega$, where $\Omega=\frac{(\mathrm{r}+\mathrm{i})}{\lambda}\left(\frac{f_{L L}}{f_{L Q}-f_{Q} / L}\right)$

Proof of Proposition 2. The effect of forest management on the amount of forest biomass used is obtained after differentiating the forest biomass equation, $Q^{*}=Q^{*}(K \Theta)$, with respect to the parameter $k$, i.e. $\frac{\delta \mathrm{Q}^{*}}{\delta \mathrm{k}} \leq 0$ subject to $Q^{*} * \Theta \leq 0$. $Q * \Theta \geq 0$ con $\Theta \geq 0$ Therefore, $\Theta \geq \Omega$ con $\Theta \geq$ 0 , where $\Theta \geq \max (\Omega, 0)$ with positive $\Omega$. This argument shows that $\Theta \geq \Omega$ and that the initial inequality is satisfied. Q.E.D.

This reasoning indicates that the increase in production to which the households are willing to agree is determined from the biomass threshold that specifies the household's expected decrease in the total provision of biomass for cutting; they are aware of this reasoning and assume the costs completely. This factor is an important determinant of the variation in the forest management parameter $k$.

If it is assumed that $f_{L L}<0, f_{L Q}>0$ and $f_{Q}>0$ for the production of charcoal, then

$$
\begin{aligned}
& \mathrm{L}^{*}>\frac{f_{L}}{f_{L Q}} \Rightarrow \frac{\delta \mathrm{Q}^{*}}{\delta \mathrm{k}}<0 \\
& \varepsilon_{L}>\sigma_{L Q} \Rightarrow \frac{\delta \mathrm{Q}^{*}}{\delta \mathrm{k}}<0
\end{aligned}
$$

where $\varepsilon_{L}$ is the elasticity resulting from $L^{*}$ and $\sigma_{L Q}$ is the substitutive elasticity between the optimal level of $\mathrm{L}^{*}$ and $Q^{*}$. These representations imply that forest management considers the level of technology used in charcoal production.

Thus, it is inferred that forest management exerts pressure on the forest resource when the elasticity resulting from work exceeds the elasticity of substitution between work and amount of biomass used after the inputs are assigned optimally. An increase in the amount of work and biomass within the system of forest management occurs if the rate of marginal return of forest work, $a$ $\left(f_{L L}-c\right)$, is greater than the exploitation cost of the amount of biomass introduced to the charcoal production system.

\section{Application: case study for Campeche, Mexico}

Area of study. The community of Chunkanán is located within the Municipality of Hecelchakán, Campeche, close to the buffer zone in the Natural Protected Biosphere Reserve of Los Petenes. It includes a total of 168 households and a population of 871 (INEGI, 2005). This urban core is within a surface of 5,015 ha of collective use property, with a total of 86 common land owners or persons with rights of land exploitation. The number of charcoal-producing households in 2007 was 45. This value represented approximately $27 \%$ of the total number of households in the community.

Instrument design. Due to the characteristics of the information required to obtain the parameters needed for the optimal control model, it was necessary to survey the 45 heads of the charcoalproducing households during 2007. Demographic, economic, social, environmental and production 
aspects of the period January-December 2006 were considered. This approach followed the methodology used to construct social accounting matrices for populations (Yunez and Taylor, 1999).

Information on the number of individuals in the household, their age, their level of education and their relationship to the household head was obtained to specify the demographic variables. In the economic section of the survey, the questions focused on the main activities performed in households, including charcoal production, wage labor within and outside the community, subsidies (productive and assistance programs) and remittances. The social section focused on the different types of support received from health, drinking water, public illumination and highways or road services. The environmental section included questions on the use of the forest resource, the average biomass used as input to charcoal production, and the most common forest species in the community.

Parameter estimation. The annual income of households from charcoal production, wage activity within and outside the community (migration), and other sources (e.g., subsidies and transfers) was obtained from the household data.

The average amount of charcoal obtained $(\mathrm{CH})$, total work L ( $\mathrm{H}$ man annual ${ }^{-1}$ ), percentage of work dedicated to cutting (g), average hours to cut a hectare (b), total of hectares in production (L/a), percentage of the household budget relative to the total use of biomass $(\mathrm{Q} \%)$, and average sale price to the intermediary $(\mathrm{P})$ were also obtained per household; poverty lines were defined according to the FGT index (Foster et al., 1984).

The rate of natural biomass growth (y) was obtained from the FMPETR. The population density was estimated from data on the total surface area of common land (A) provided by the community authority. The number of households (n) was obtained from the II population and housing census data (2005) of the Instituto Nacional de Estadística y Geografía (INEGI). The minimum wage was obtained from the Secretaria de Administración Tributaria (SAT). Parameter $k$ was estimated from the average surface area used by traditional management and from the forest surface areas proposed for inclusion in annual charcoal production activity under the forest management program specified by the FMPETR.

Considerations for the calibration of the empirical model. It is assumed that households react to the policy of forest management by adjusting their level of effort to the proposed forest surface. Specifically, they will apply the variable work $L(t)$ to the surfaces specified by the management program according to parameter $k$. By representing the variation produced by different forest management policies, this parameter enables the implementation of a simulation to compare the current traditional forest management approach with the FMPETR. The parameters represent the model restrictions, given a rate of marginal return from forest work greater than or equal to the opportunity cost of using the biomass in period $t$ rather than in period $t+1$. In addition, the total surface used by households is adjusted to the level established as the acceptable use threshold for the forest biomass, completely internalizing the social costs.

Obtaining an annual average productive surface value was another important aspect of the simulation and of the comparison of the current traditional management approach with the FMPETR. The FMPETR does not consider stable averages. Instead, it considers surfaces whose amounts vary from high to low during successive years, for a total of 5 periods. The annual average productive surface value obtained for the FMPETR was $k=1.59$, whereas $\mathrm{k}=1$ for traditional management. These values considered the total average surface of 64.35 ha used annually by the charcoal producers. A simulation of the bioeconomic optimal control model over a 35-year planning horizon was performed to observe the effects on the amount of forest biomass used, the work invested and charcoal production obtained from the alternative forest management strategies considered in the study. Table 2 shows the forest 
management parameters $k$ used to establish the optimal control model.

Model calibration. The Vensim DSS 5 program (Ventana System Inc., Harvard, Massachusetts, US; www.vensim.com/software.html) was used in the analysis of the model. This program constructs a flow diagram that allows the inclusion of the estimated parameters and of the initial and final periods to determine the optimal expansion paths for each type of forest management. Figure 1 shows a flow diagram explaining the structure of the optimal control model for charcoal production.

Social pressure on forest surfaces in the community is related to the parameter of forest management $k$, the total number of charcoal-producing households (n), the total land supplied to the community (A) and the average surface area used (Figure 1). The social pressure impacts the change (variation) in the forest biomass in each productive cycle.

The variation in biomass in each cycle associated with the average of biomass present in the forest

Table 2. Parameters of forest management policies for the calibration of the optimal control model for the Chunkanán Community, Campeche, Mexico.

\begin{tabular}{lcc}
\hline Year & $\begin{array}{c}\text { Traditional Management } \\
\text { Value for periods } k\end{array}$ & $\begin{array}{c}\text { Forest Management Program (FMPETR) } \\
\text { Value for periods } k^{1}\end{array}$ \\
\hline 1 & 1 & 2.83 \\
2 & 1 & 2.06 \\
3 & 1 & 1.72 \\
4 & 1 & 1.28 \\
5 & 1 & 0.93
\end{tabular}

${ }^{1}$ These values were obtained considering the annual average surface used by the traditional practice, 64.6 ha for 2006. Source: Authors' own calculations derived from a household survey of Chunkanan charcoal producers, 2007, and the Forest Management Program for the Exploitation of Timber Resources (FMPETR), National Forest Commission - Natural Resources and Environmental Secretary (Mexico), 2006.

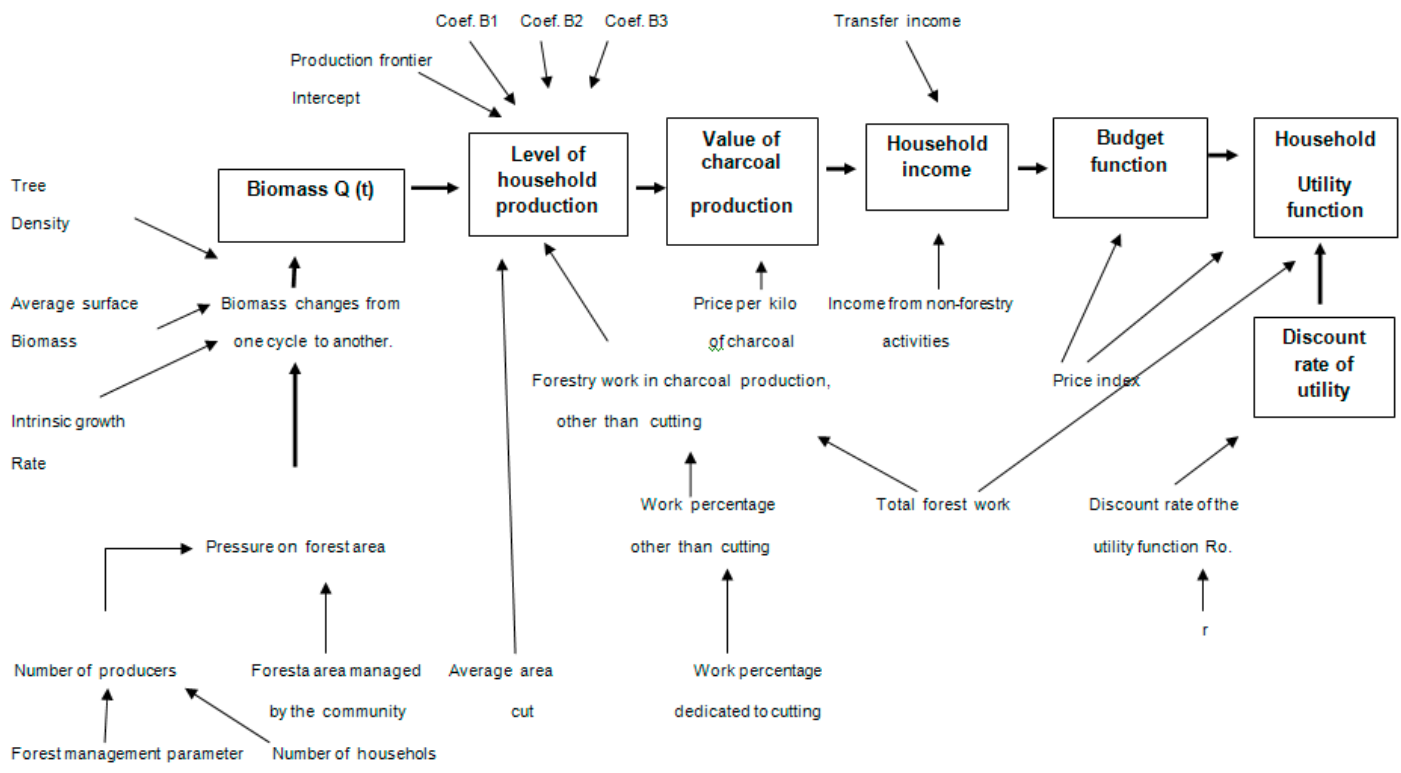

Figure 1. Flow diagram describing the structure of the optimal control model for charcoal production. 
surface and the index of tree density effectively impacts the use of total biomass by the community.

Moreover, the use of forest biomass, the production function (representing the artisanal furnace technique) and the amount of forest work applied to production will be reflected in the level of household production. The level of production is affected by the sale price received by the producer (established exogenously) as fixed by commercial intermediaries, which determines the production value.

The productive income is integrated with the monetary income obtained from wage labor in other activities within and outside the community, as well as by the transfers received (subsidies and productive support by the government). Therefore, this cluster of incomes is part of the total household income. The total household income is an integrative component of the household budget and directly influences the household's utility function.

\section{Results and discussion}

The analysis of the results indicates that the producing households are economically poor. The households with abject poverty, fixed poverty and non-poor status (the F-G-T index) received total monthly per capita incomes of US\$ 40.51, US\$ 65.33 and US\$93.80, respectively. These amounts are equivalent to daily per capita incomes of US\$ 1.35 , US\$ 2.17 and US\$ 3.12, respectively.

Charcoal production by these households represents only $33 \%$ of the total income. Wage labor represents $46 \%$, other income $21 \%$. Together, these sources of income allow the families to meet their basic needs for food.

The following parameter values were obtained as the estimates in a linearized model of a Cobb-Douglas type production function (García et al., 2007), where $\alpha=-0.8180$ and coefficients $\beta_{1}=0.559, \beta_{2}=0.482$ and $\beta_{3}=-0.206$. The technology of artisanal production shows decreasing production yields $(0.835)$.
Therefore, the production levels for households were determined by the following equation:

$$
C H_{i}=6.158^{*}(L / a)_{i}^{.559} *((1-g) L)_{i}^{.482} *\left(Q_{0}\right)_{i}^{-.206}
$$

Results from the model with traditional forest management. The estimates obtained to establish the parameters of the model assuming traditional forest management showed that a representative producing household had an average annual production $\left(\mathrm{CH}_{i}\right)$ of $10.10 \mathrm{t}$, forest work of 994 (h annual $\left.{ }^{-1}\right)$, a percentage of work performed in biomass cutting $(g)$ of 0.32 , an average of $266.60\left(\mathrm{~h} \mathrm{ha}^{-1}\right)$ for tree cutting, an annual average surface used per household $\left(\frac{L_{i}}{a_{i}}\right)$ of $1.43 \mathrm{ha}$, an average forest biomass used per ha of $13.16 \mathrm{t}$, an intrinsic rate of growth of the community surface $(\gamma)$ of $15 \%$, a rate of use of forest biomass by the producing households $Q(t)$ of $4.5 \%$, an average price per $\mathrm{kg}$ of charcoal of $\$$ 0.11 (\$ will henceforth denote Mexican pesos), and a total provision of work from the producing household of 1,749 $\mathrm{H}$. In addition, a representative producing household had an annual average income of $\$ 3,361.67$. This amount included an income of $\$ 1,112.42$ from charcoal production, an income of $\$ 1,758.71$ for work outside the forest sector, and other income of $\$ 490.52$. These data are used as a baseline for the dynamic simulation.

The following scenario would develop if charcoal production is strengthened as the principal productive activity of producing households in the community of Chunkanán, if the households decide to increase their large-scale-production efforts, and if the producers maintain the current traditional slash-and-burn forest management approach with land rotation. Under this scenario, the amount of hours invested in forest work over a 5-year period would be $1,892 \mathrm{~h}$ annual- ${ }^{-1}$, the use of biomass would increase from 4.5 to $7.5 \%$, the amount of production would increase to 11.89 $\mathrm{t}$ and the income would increase to $\$ 1,309.32$, increasing the surface exploited per household from 1.44 to 2.34 ha annually. Table 3 presents the parameters used in the calibration of the optimal control model. 
Note that the increased surface used for charcoal production results because the rate of marginal return from forest work is higher than the opportunity cost of the biomass used in production, in addition to the decreasing yields shown by the production function. This result is based on the assumption that artisanal furnaces represent the technology used for charcoal production. Figure 2 presents the percentage of biomass used by the traditional and FMPETR exploitation strategies over a 35 -year period.

Results from the model with FMPETR. If this forest management approach is applied, tree cutting is technology intensive, involving the massive use of chainsaws, and it therefore requires fewer hours of forest work. A total amount of forest work of $1,189 \mathrm{~h}_{\text {year }}{ }^{-1}$ would be invested, the biomass use would be $7.76 \%$, the production would increase to $10.90 \mathrm{t}$, and the income would increase to $\$ 1200.14$. A total surface use of 2.14 ha year household ${ }^{-1}$ would be used in the first year. A total of 2.42 ha year household ${ }^{-1}$ would be used in the last year, the end of the period of application of the 5 -year program. Figure 3 shows the level of production per household $(\mathrm{kg})$ for the traditional and FMPETR exploitation strategies over a 35-year period.

Comparative results from traditional forest management and FMPETR. The comparison of the levels of biomass use and the amount produced for traditional forest management and FMPETR shows that traditional management maintains a increasing dynamic level of biomass use. The rate of biomass use would be equal to the intrinsic rate of biomass growth in year 18 , with a use percentage of $15.31 \%$; the level of production would reach $15.96 \mathrm{t}$, equivalent to an approximate income of $\$ 1,757.26$. Table 4 summarizes the results obtained from the optimal control model in terms of biomass, production and monetary income.

The initial point of forest management with the FMPETR corresponds to $k=1.59$, equivalent to an average 102.23 ha of total surface used by the

Table 3. Parameters used in model calibration.

\begin{tabular}{|c|c|c|c|c|}
\hline Parameter & Average & $\begin{array}{l}\text { Standard } \\
\text { deviation }\end{array}$ & Minimum & Maximum \\
\hline Average annual income $(\mathrm{Y}), \$$ & $3,361.67$ & $1,426.50$ & $1,228.58$ & $7,443.05$ \\
\hline Charcoal income $(\mathrm{CH}), \$$ & $1,112.42$ & 812.27 & 118.91 & $4,280.85$ \\
\hline Wage labor income c(T-L), \$ & $1,758.71$ & $2,318.77$ & - & $14,063.07$ \\
\hline Other income (E), $\$$ & 490.52 & 348.12 & - & $1,294.09$ \\
\hline Amount of charcoal produced $(\mathrm{CH}), \mathrm{kg}$ & $10,101.44$ & $7,381.94$ & $1,080.00$ & $38,880.00$ \\
\hline Total work hours men annual ${ }^{-1}, \mathrm{~L}$ & 994.00 & 469.22 & 264.00 & $2,256.00$ \\
\hline Percentage of forest work dedicated to the cutting of trees, $g$ & 0.32 & 0.07 & 0.18 & 0.45 \\
\hline Average hours to cut a hectare (b) & 266.00 & 245.87 & 96.00 & $1,728.00$ \\
\hline Total hectares used in production $(\mathrm{L} / \mathrm{a})$ & 1.44 & 0.76 & 0.50 & 4.00 \\
\hline Biomass of trees used in production (Wo), $\mathrm{t} \mathrm{ha}^{-1}$ & 11.42 & 7.05 & 1.79 & 44.64 \\
\hline Relative percentage of biomass using total household budget $(\mathrm{Q})$ & 4.500 & 0.884 & 0.310 & 6.100 \\
\hline Intrinsic rate of natural increase of biomass $(\mathrm{y})$ & 15.00 & $\mathrm{n} / \mathrm{a}$ & $\mathrm{n} / \mathrm{a}$ & $\mathrm{n} / \mathrm{a}$ \\
\hline Purchase price for the producer $(\mathrm{P})$ & 1.20 & $\mathrm{n} / \mathrm{a}$ & $\mathrm{n} / \mathrm{a}$ & $\mathrm{n} / \mathrm{a}$ \\
\hline Population density (n/A), home ha-1 & 0.0087 & $\mathrm{n} / \mathrm{a}$ & $\mathrm{n} / \mathrm{a}$ & $\mathrm{n} / \mathrm{a}$ \\
\hline Forest management parameter $(\mathrm{K})$ & 1.00 & $\mathrm{n} / \mathrm{a}$ & $\mathrm{n} / \mathrm{a}$ & $\mathrm{n} / \mathrm{a}$ \\
\hline Allocation of household's total annual working hours (Ti) & $1,749.00$ & $\mathrm{n} / \mathrm{a}$ & $\mathrm{n} / \mathrm{a}$ & $\mathrm{n} / \mathrm{a}$ \\
\hline Minimum wage (c) & 47.60 & $\mathrm{n} / \mathrm{a}$ & $\mathrm{n} / \mathrm{a}$ & $\mathrm{n} / \mathrm{a}$ \\
\hline
\end{tabular}

\$ in Mexican pesos; average annual exchange rate \$ 10.90 pesos per US dollar, 2006. n/a: Not applicable. 


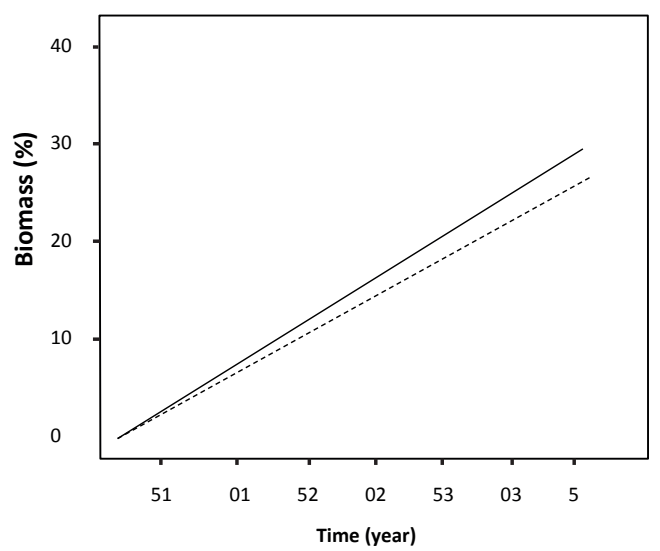

Figure 2. Percentage of forest biomass used by alternative management strategies over a 35-year period. Percentage of Biomass using the FMPETR Exploitation Strategy. Percentage of biomass using the Traditional Exploitation Strategy

producers. This value affects ecological sustainability because it becomes equal to the intrinsic rate of growth in a shorter period (16 years) than that found for traditional management. Under the FMPETR approach, these values are associated with a percentage of biomass use of $14.94 \%$, a production level of $12.31 \mathrm{t}$, and an equivalent income of approximately $\$ 1,355.38$. The change of surface use begins in year 1 at 2.14 ha household $^{-1}$ and ends in year 16 at 3.40 ha household ${ }^{-1}$. This information implies a higher degree of pressure on the forest resource.

In addition, the increased use of forest biomass proposed by FMPETR in the first productive cycles impacts the $\mathrm{Q}(\mathrm{t})$ equations, the assignment

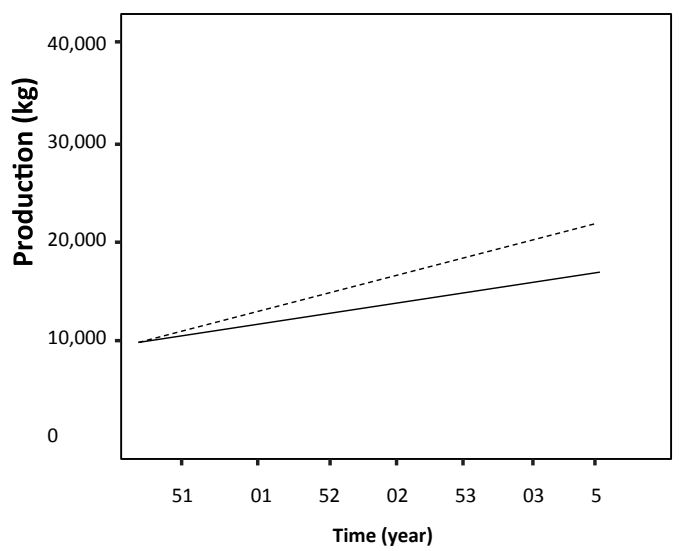

Figure 3. Level of production per household $(\mathrm{kg})$ for each exploitation strategy over a 35 -year period. Level of Household Production using the FMPETR Exploitation Strategy. Level of Household Production using the Traditional Exploitation Strategy

of forest work and the surfaces used. These factors place the future incomes of households at risk because they decrease the level of production and promote the loss of soil quality (because all trees are cut) in the short, medium and long term. This pattern of negative impacts is in contrast to the outcomes to the community that result from traditional management.

In conclusion, the comparison between the two alternatives for forest management (traditional and FMPETR) shows that households assign an optimal amount of forest work if the rate of marginal return of forest work is greater than or equal to the opportunity cost of using biomass in the current period $(\mathrm{t})$ rather than in the following period $(\mathrm{t}+1)$.

Table 4. Results of the optimal control model for biomass, production and household income.

\begin{tabular}{llccccc}
\hline & \multicolumn{5}{c}{ Year } \\
\cline { 2 - 7 } & Baseline & 5 & 10 & 20 & 30 & 35 \\
\hline Biomass, $\%$ & & & & & \\
Traditional $(k=1)$ & 4.50 & 7.50 & 10.50 & 16.51 & 22.52 & 25.52 \\
FMPETR $(k=1.59)$ & 4.50 & 7.76 & 11.03 & 17.56 & 24.09 & 27.35 \\
Production, $\mathrm{t}$ & & & & & 20.67 \\
Traditional $(k=1)$ & 10.10 & 11.89 & 13.53 & 16.54 & 19.33 & 14.78 \\
FMPETR $(k=1.59)$ & 10.10 & 10.90 & 11.62 & 12.96 & 14.19 & \\
Income, American dollars & & & & & \\
Traditional $(k=1), \$$ & $1,112.05$ & $1,309.36$ & $1,490.04$ & $1,821.12$ & $2,128.32$ & $2,275.52$ \\
FMPETR $(k=1.59), \$$ & $1,112.05$ & $1,200.14$ & $1,279.41$ & $1,427.28$ & $1,562.60$ & $1,627.67$ \\
\hline
\end{tabular}

\$: Annual average exchange rate of $\$ 10.90$ pesos per U.S. dollar, 2006. 
This approach is effective because it involves the possibility of reusing the surface for agriculture in the same cycle and decreases the opportunity cost of the hours invested in surface cutting.

In addition, it was observed that charcoal-producing households internalize the social costs from the use of forest biomass, as the rate of use of forest biomass is close to the intrinsic rate of vegetation growth; they diminish the pressure on the use of the resource through an average decrease in the amount of surface area exploited for this activity.

Note that the FMPETR does not determine a change in the technology used for charcoal production, which currently shows decreasing yields. To a certain extent, this characteristic limits the analysis presented of the two alternative approaches to forest management because a sensitivity analysis considering a change in production functions was not possible. The findings of such an analysis might change the initial and final conditions used in the optimal control model.

The results of this study demonstrate empirically that the Mayan communities located near the Biosphere Reserve Los Petenes, Mexico, practice sustainable management of their forest resources because their levels of use of the forest biomass are less than the intrinsic rates of growth. These communities obtain a positive monetary income from charcoal production. In addition, they use these forest surfaces for agricultural production. This approach allows the optimization of the work invested by the household.
Consequently, the primary policy recommendation derived from this work is that the Secretaría de Medioambiente y Recursos Naturales (SEMARNAT) of Mexico should promote plans for forest management based on considerations of economic conditions in addition to identifying the complementarity of forest and agricultural activities. These economic and complementarity factors determine the economical and social incentives associated with the use of forest surfaces. In this particular case, the bioeconomic analysis developed in this study suggests that maintaining the traditional management approach, the slash-and-burn system applied to small surfaces, represents an optimal policy because it allows the producers to maintain this forest activity in combination with agricultural production, decreasing the additional pressure on the forest resource and optimizing the amount of work assigned to the cutting of biomass on the local scale. This approach represents an improved social decision-making process because it does not impose pressure on the threshold of biomass use expected by each family. Thus, the results of this study show the need for a deeper analysis of the economic and social incentives for using the forest resource in these communities. The analysis will be of value to Latin American decision makers in clearly defining ways to increase the cost-effectiveness of management and environmental conservation policies in indigenous communities located close to protected natural areas.

\section{Resumen}

F. Arrocha y M.G. Villena. 2012. Aplicación un Modelo bio-económico de control óptimo a la producción de carbón vegetal: el caso de las Comunidades Agrícolas de Roza-TumbaQuema en México. Cien. Inv. Agr. 39(2): 489-504. Este trabajo analiza las relaciones entre pobreza rural y el manejo de las tierras forestales en el contexto de la producción de carbón vegetal bajo roza-tumba- quema. Un modelo de control óptimo determina cómo un hogar representativo toma decisiones sobre la asignación de trabajo y superficies forestales a utilizar, mismas que afectan la base de este recurso renovable del cual depende. El modelo de control 
óptimo propuesto para la producción de carbón vegetal, está basado en el modelo agrícola de roza-tumba-quema de Pascual and Barbier (2007). Este modelo teórico es calibrado con datos de la comunidad de Chunkanán, Campeche, México. La simulación y comparación del manejo forestal tradicional de roza-tumba-quema, con respecto al programa de manejo forestal para el aprovechamiento de los recursos forestales maderables (PMFARMF) propuesto como política de uso y conservación del recurso forestal por la autoridad regulatoria, demostró que el primero, y no el segundo, es sostenible desde el punto de vista ecológico y eficiente desde el punto de vista económico, donde los hogares asignan una cantidad óptima de trabajo y biomasa forestal. Este resultado sugiere que el PMFARMF es una política subóptima, existiendo espacio para mejorar en términos del diseño e implementación de políticas que apunten a proveer incentivos económicos y sociales para el manejo sostenible de recursos naturales.

Palabras clave: Hogares rurales, manejo forestal, pobreza rural, producción de carbón vegetal.

\section{References}

Arrocha, M. 2007. La contribución del recurso forestal hacia los hogares rurales de la zona aledaña al Área Natural Protegida Reserva de la Biosfera Los Petenes: Un cálculo del incentivo económico de conservación, San Francisco de Campeche, México. Indesol - Kairos, A.C. 80 pp.

Foster, J., J. Greer, and E. Thorbecke. 1984. A class of decomposable poverty measures. Econometrica $81: 761-766$.

García, A., N. Ceular, J.M. Caridad, R. Acero, J.M. Perea, and M.E. Martín. 2007. Determinación de funciones de producción y análisis de eficiencia de la invernada pampeana Argentina. Córdova, España. Archivos de Zootecnia 56(213):23-32.

INEGI. 2005. II Conteo Nacional de Población y Vivienda. Instituto Nacional de Estadística, Informática y Geografía (INEGI). México, D.F. 648 pp.
Lucio, J. 2006. Programa de Manejo Forestal para el Aprovechamiento de los Recursos Forestales Maderables. Comisión Nacional Forestal (CONAFOR). San Francisco de Campeche, México. 110 pp.

Lopez, R. 1997. Environmental externalities in traditional and the impact of trade liberalization: the case of Ghana. Journal of Development Economics 53:17-39.

Pascual, U., and E.B. Barbier. 2007. On price liberalization, poverty and shifting cultivation: An example from Mexico. Land Economics 83:192216.

Pascual, U. and R. Martínez-Espiñeira. 2006. Second-best policy options against poverty and environmental degradation in forest based agricultural systems. Economía Agraria y Recursos Naturales 12:121-144.

Yunez, A and E.J. Taylor. 1999. Manual para la construcción de matrices de contabilidad social para pueblos. Colegio de México. México, D.F. 104 pp. 